The 16th Economic International Conference

New Challenges and Opportunities for the Economy 4.0,

May 7-8th, 2020, Suceava, Romania

\title{
A Delicate Balance: Transparency and Privacy in State of Emergency
}

\author{
Raluca ONUFREICIUC
}

https://doi.org/10.18662/lumproc/ncoe4.0.2020/26

How to cite: Onufreiciuc, R. (2020). A Delicate Balance: Transparency and Privacy in State of Emergency. In C. Nastase (vol. ed.), Lumen Proceedings: Vol. 13. 16th Economic International Conference NCOE 4.0 2020 (pp. 299-309). Iasi, Romania: LUMEN Publishing House. https://doi.org/10.18662/lumproc/ncoe4.0.2020/26 


\title{
A Delicate Balance: Transparency and Privacy in State of Emergency
}

\author{
Raluca ONUFREICIUC ${ }^{1}$
}

\begin{abstract}
Privacy and transparency are not mutually exclusive, but rather two sides of the same coin. The principle of transparency plays an essential role in encouraging citizens to participate actively in the democratic life of the European Union and the right to privacy is a constitutional right which is guaranteed for everyone in what regards personal or professional life.

In a state of emergency case, the need for transparency in decision making and accountability are essential to increase public trust and clarity in government actions and measures. In terms of enhanced protection of personal data, it is of ultimate importance to differentiate between how government can use public health data and how employers can contribute to a vital public bealth cause. In this context, identifying and analyzing the proper mechanisms and adequate methods that can be used, are a necessity and can play a crucial role in dealing with future challenges and changes in the public or private space.
\end{abstract}

Keywords: transparency; digital dividend; right to privacy; state of emergency; government response; flexibility clauses; economic challenges.

\footnotetext{
${ }^{1} \mathrm{PhD}$ candidate University of Bucharest and University of A Coruna, Bucharest/A Coruna, Romania/Spain, onufreiciuc.raluca@,drept.unibuc.ro/raluca.onufreiciuc@udc.es 


\section{Introduction}

Over time the European approach to formal and informal "grassroots" consultations, the clarity of these procedures and the promptness of the decision-makers to the questions raised by their stakeholders were towards an increased institutional transparency which have almost continuously ensured and sustained the democratic legitimacy of the European institutions.

In the context of the new regulatory framework of enhanced protection of personal data, it is imperative that the challenges and limitations on the availability and accessibility of data and information are rigorously identified as being of public interest at EU level in the joint effort of the European institutions to comply with the requirements of transparency, confidentiality and integrity. The same values were unveiled in the European data strategy $(\operatorname{COM}(2020) 66$ final) which underlined that "citizens should be empowered to make better decisions based on insights gleaned from nompersonal data and that data should be available to all - whether public or private, big or small, start-up or giant". In this way, one of the main positive results is that society will be helped "to get the most out of innovation and competition and ensure that everyone benefits from a digital dividend" [1]. The European data strategy's public online consultation is available until May $31^{\text {st }}, 2020$.

Also, a very important part of this strategy was the publishing of a report on Business-to-Government (B2G) data sharing which emphasizes in a much clearer way the relationship between transparency, citizen engagement and ethics.

\section{State of emergency: a possible tech Trojan horse?}

State of emergency [2], as defined by the Cambridge English dictionary, is a temporary system of rules to deal with an extremely dangerous and difficult situation. In expressing his concerns about the transformation of a country due to the state of emergency declaration, Giorgio Agamben [3] affirmed that a state of exception produces both "a new form of social relation, namely one of generalized, limitless control". Moreover, in this case, the active participation of every citizen is not anymore needed, as they are seen as a group of people who needs to be protected by the state. The same idea was strengthened by other authors[4] by examining the "us versus them" perception and the impact that could have on "the already stretched European democracies". 
The European Convention on Human Rights in article 15 allows every country to decide whether to declare or not state of emergency "in times of war or other public emergency threatening the life of the nation". Analyzing the current pandemic situation, six countries, part of ECHR have declared a state of emergency under Article 15 (Romania, Moldova, Latvia, Estonia, Georgia and Armenia[5]. One of the most affected countries Italy and Spain did not have the same optics and declared state of emergency in accordance with their own constitutional provisions. For example, in Italy, in arguing how governments act in emergency situations when the interests of the private might be affected, Agamben[6] criticized that state authorities, in the name of safety "that they alone can ostensibly guarantee", imposed restrictions on Italian citizens and limited their freedoms. It is significantly important to mention that in exercising emergency powers, state authorities are not required a specific timeframe for reestablishing citizens' rights at a crisis' conclusion [7]. One major challenge is faced by the countries that "suffer" from a insufficient governmental transparency such as Iran where a pattern of restrictions on freedom of expression and media freedom was very criticized. Although it is too early to say decisively, these crisis based actions could sharpen even more the differences that still persist between democratic and authoritarian states. In other words active monitoring and vigilance on the compliance of the taken measures with the national and international law are absolutely necessary [8] or as Professor Yuval Noah Harari quoted "if we are not careful, this epidemic can give justification for the accelerating development of the totalitarian regime." One possible solution can be represented by a further revision of ECHR provisions.

In order to confront the present pandemic crisis, many Member States launched or express their plans to launch initiatives that involve contact tracing apps in the fight against Covid-19. One of the first pioneers in what regards contact tracing apps was Singapore which at the end of March initiated Trace Together, Safer Together [9]. The aim of this application was to "identify people who have been within $2 \mathrm{~m}$ of coronavirus patients for at least 30 minutes, using wireless Bluetooth technology." One of the main advantages that the developers [10] of this app outlined is its role of helping the people infected to recall whom they had been in close proximity with for a long period of time. As a consequence a long-lasting process of tracing contacts that is normally carried out manually by public health authorities and rely on patients' own memories would be shortened and more accurate and efficient. It is clearly understandable that these mobile applications will not totally replace the manual contract tracing especially if we take into consideration the elder people who are more vulnerable to the 
infection and could be less likely to have a mobile phone or access to internet[11]. For example, the Austrian Red Cross launched the Stopp corona-App [12] which by using "digital handshake" can determine anonymously how many people were exposed to a person that shows symptoms of the corona infection. Another proposal comes from Germany which plans a cross-border approach to the application development operation to reduce the risk of interoperability difficulties between nationally developed applications by initiating the Pan European Privacy-Preserving proximity Tracking platform [13] (PEPP-PT) which brings together over 130researchers and specialists from 8 countries. The three basic principles that found the basis of this core technology are cooperation, international applicability and compliance with the General Data Protection Regulation (GDPR). In fact, one of the key characteristics of this open protocol for proximity tracing is that "personal data stays entirely on an individual's phone". Other initiatives of the EU Member States that are supported by the PEPP-PT were detailed in the eHealth Network's Common EU Toolbox for Member States (e.g. France or Denmark). In other countries in which these mobile applications are still under development, many debates and discussions were generated especially related to the topic of secure communication and compliance with data privacy protection regulation.

In confronting this pandemic crisis, Poland was one of the first European countries to develop and enforce the use of corona-virus related applications [14]. Being at first optional, the app has been installed only on about 230,000 devices, but once the number of the people requiring quarantines grew, it became compulsory. Therefore, on $1^{\text {st }}$ of April, the Polish government announced that the only exceptions that were admitted from not using it regarded blind people or who werevisually impaired and those who signed a "declaration confirming they do not use telecommunications networks or have a smartphone". The major inconvenience for the Polish citizens, besides the excessive fine of approximately $\$ 11,200$ and a police visit in case of not installing it, consisted of the errors that the usage of geolocation and facial recognition algorithms generated. In many cases, police authorities, in verifying if the citizens respected or not the quarantine residence and rules, received false alarms created by situations like failure to send a selfie, disconnections or discharged phone batteries or even not paying attention to an alert because citizens were taken a longer shower than usual. In what concerns the length of time citizens' personal data could be stored, the Polish government gave assurances that the retention is only for six years and could be accessed only by a limited state authorities such as the Centre for Information Technology, National Centre for Healthcare Information Systems, police and developers. 
Several researchers including cyber security expert JanZygmuntowski expressed their reservations about the privacy and security of the application. He also underlined that the effects of the new voluntary contact tracing app are still debatable and in his opinion the application has many issues on privacy and how the data would be used in the future. In the process of differentiating the two apps, he affirmed: "It shows the location, it shows the time, it shows your face — but it's not so much of a worry as the contact-tracing one." Taking this into consideration, I believe that there are still many unknown"equations" to be solved regarding the civil society reaction towards these apps in a common pre-existent context of limited trust in both national and local public authorities and institutions.

\section{Optional vs. Mandatory tools}

One of the first issues that provoked many debates and needed immediate official answers concerned the use of these applications and implicitly its mandatory or optionalcharacter for the citizens of the European Union. The EU Commission suggested that "the obligation to use an application which affects the rights to the confidentiality of communications [...] can be imposed only by means of a law which is necessary, appropriate and proportionate to protect certain specific objectives [...]. For these reasons, the Commission recommends the use of optional applications." [15]

In what regards who will have access to this data, the EU Commission considers that all the mobile applications should be designed in such a way that national health authorities (or entities performing tasks of public interest in the field of health) are data controllers. For example, the Pan European Privacy-Preserving proximity Tracking platform publicly stated on their website that their design is able to "record as little data as possible". Moreover, they stated that by using an unique user such as ID (UUID) which is keeping the citizen's anonymity, the maximum period of time the app canrecord a personal phone number is only 30 days. Any other data such as human behavior or geolocation will not be recorded.

On $21^{\text {st }}$ of April, the European Data Protection Board[16] adopted a document called Guidelines on the use of location data and contact tracing tools in the context of the Covid-19 outbreak underlining firmly that "data and technology used to help fight Covid-19 should be used to empower, rather than to control, stigmatise, or repress individuals". In addition to this the document reminded clearly every Member State or EU institutions that any measure taken by them requires to be guided by the general principles of effectiveness, necessity and proportionality. In a dialogue[17] with Olivier 
Micol, Head of Unit European Commission (DG for Justice and Consumers unit C.3 -Data Protection), the chair of the European Data Protection Board, Andrea Jelinek, specified that the fact "the use of the contact tracing takes place on a voluntary basis does not mean that the processing of personal data by public authorities necessarily be based on the consent". One useful example that can be mentioned is the usage of Immuni app [18] in Italy which even though was entirely voluntarily at the beginning step by step was considered mandatory by Italian private companies and local institutions. The attempt of the national authorities in suggesting support and a massive adoption became shortly an obligation at the local level. In assuring that the contact tracing app is in line with the European privacy rules and data protection authority, Italy estimated that the app needs a $60 \%$ of the population[19] usage in order to be effective and make the system work.

\section{A more transparent path: accessibility vs. efficiency}

The European Data Protection Board also emphasized that one of the conditions to ensure the efficiency of these tools is the "percentage of people who would need to install it". A study[20] of Oxford University's Big Data Institute affirmed that at least $60 \%$ of a country's population would need to be involved and install the app in order for it to be effective. In the below graphic (Fig.1) using the updated data from Digital 2020[21] for the following 18 EU countries (Austria, Belgium, Bulgaria, Croatia, Czech Republic, Denmark, Estonia, France, Germany, Greece, Italy, Netherlands, Poland, Portugal, Romania, Spain, Sweden, Switzerland) and Non-EU countries (UK, China, Japan, USA, Russian Federation and South Korea), I aim to determine which are the countries thathave the highest possibility to succeed in implementing these tools taking into consideration two key factors: the percentage of smartphone penetration in a group of age between 16-64 years and the existent rate of infection with corona virus in every aforementioned country. A living example is South Korea good case practice[22] in which the large number of smartphone users (almost 96\%) doubled by the strong previous support of civil society, and had "overwhelmingly positive reviews". As we can observe, the two EU Member States that have the same high percentage of $94 \%$ are Italy and Spain which were also the first and most affected countries by this pandemic crisis. Romania, even tough has a larger population than Netherlands has a much smaller percentage only of $88 \%$ in comparison with $92 \%$ Dutch smartphone penetration. Interestingly enough, the leader in Europe is Switzerland which 
currently announced that on May 11th is launching a decentralized contact tracing app DP-3T, a project which is part of Swiss National Covid-19 Science Task Force[23], a national scientific advisory board. We assume that this high percentage could have been determinant in opting for a decentralized approach, instead of a cross-border approach. As is wellknown recently Apple and Google joined forces and assured that they will provide an unique technology solution declining to discuss "the implications [24] of the countries that opt to go it alone". What is clearly certain is that as a general rule no matter the size of the population or percentage of smartphone penetration, once the crisis is over, every country should not maintain these tools in use and all the collected data should be erased or at least anonymized. One possible solution would be a common and transparent approach of erasing guidelines followed by a national report describing the impact and level of data usage.

Fig. 1. Smartphone penetration by country

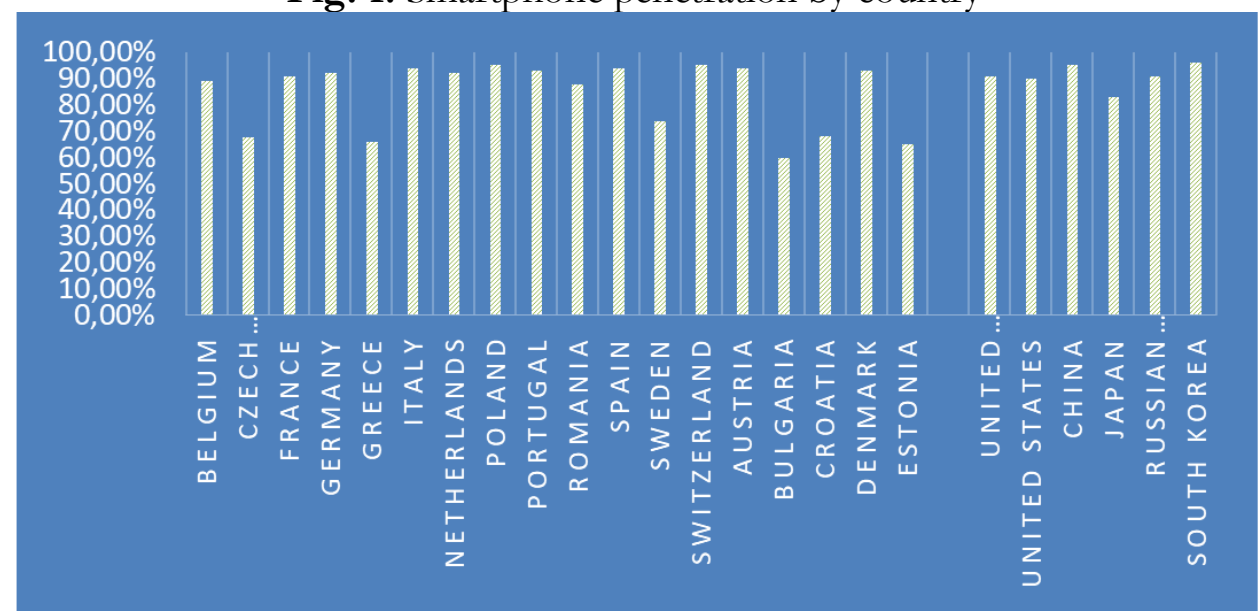

Source: Digital 2020. Global Digital Overvien

In what regards, the efficiency of the mobile application, a good predictive factor is the Singapore case where about one million people[25] have downloaded Singapore's contact tracing app, but the tool needed at least three-quarters of Singapore's population, approximately 4.3 million people. In the graphic below (Fig. 2), my target was to create a visual representation connecting the number of smartphone users and coronavirus cases in each the analyzed countries. For example, outside the European Union, South Korea started using the app early in the outbreak and ended having a very small number of infections $(10,774)$ taking into consideration that the South Korean authorities took very few restrictions. In the 
European Union, Croatia is one of the countries that has a small number of cases $(2,076)$ and a medium smartphone percentage of $68 \%$ which raises the question if these kind of tools are in fact useful in every EU country as a joint initiative. In UK, the National Health System (NHS) is expected to approve the first version of the contact tracing app until May $15^{\text {th }}$ and it is expected to reject the Apple-Google system, as stated in a BBC article[26] at the end of April.

Fig. 2. Visual representation of smartphone penetration and Covid-19 cases by country

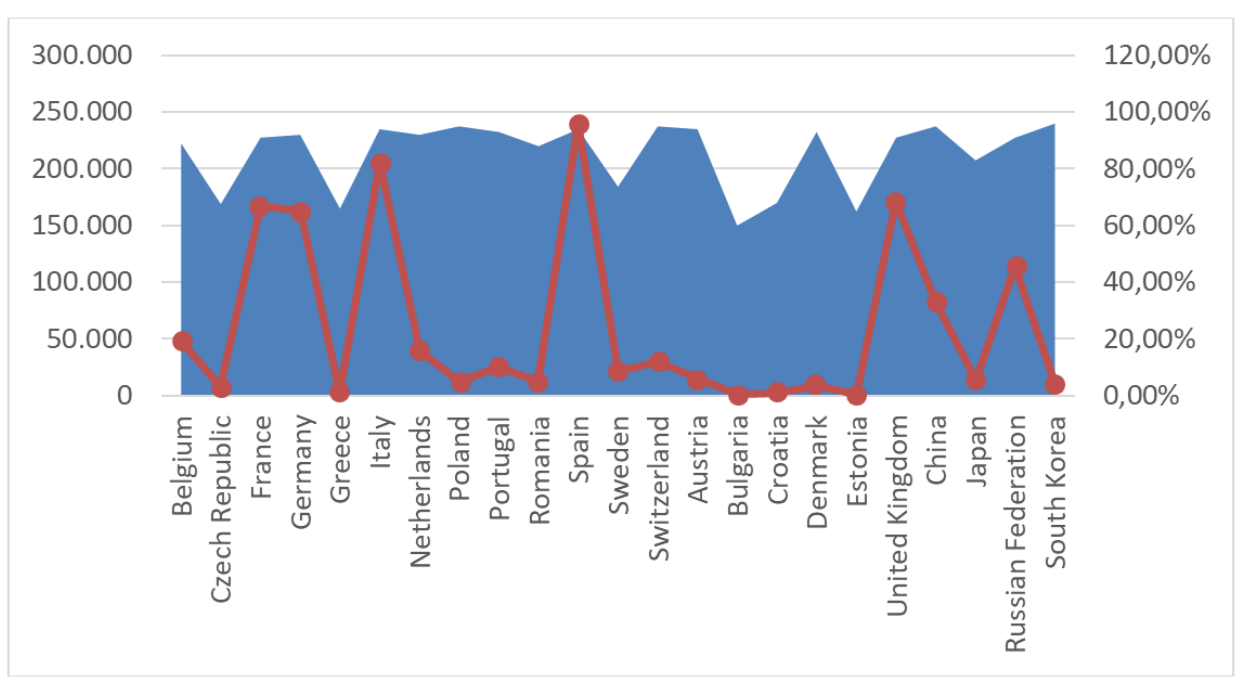

\section{Conclusion}

Before encouraging massive downloads and the citizens to use these new technological solutions against coronavirus, it is of utmost importance that every state hasa clear outcome and evaluation of the real impact it can have on privacy, decision-making transparency and fundamentals human rights.

\section{Acknowledgements}

This paper was co-financed from the Human Capital Operational Program 2014-2020, project number POCU / 380/6/13/125245 no. 36482 / 23.05.2019 "Excellence in interdisciplinary $\mathrm{PhD}$ and post- $\mathrm{PhD}$ research, 
career alternatives through entrepreneurial initiative (EXCIA)", coordinator The Bucharest University of Economic Studies”.

\section{References}

[1] COMM (2020) 66 final, European Data Strategy, February 19th Brussles; 2020. Available from: https://ec.europa.eu/info/sites/info/files/communicationeuropean-strategy-data-19feb2020 en.pdf, accessed on 25.04.2020.

[2]Cambridge Dictionary Online. Available from: https://dictionary.cambridge.org/dictionary/english/state-of-emergency, accessed on 23.04.2020.

[3] Agamben G. "Giorgio Agamben: 'De l'Etat de droit à l'Etat de sécurité", Le Monde, 23/12/2015. Available from: http://www.lemonde.fr/idees/article/2015/12/23/de-l- etat-de- droit-a- 1etat- de-securite $48368163232 . \mathrm{html}$, accessed on 24.04.2020.

[4] Aradau C, Van Munster R.. Exceptionalism and the 'War on Terror', The British Journal of Criminology. 2009; 49(5).

[5] State of Emergency: how different countries are invoking extra powers to stop the coronavirus, The Conversation. Available from: https://theconversation.com/state-of-emergency-how-different-countries-areinvoking-extra-powers-to-stop-the-coronavirus-134495

[6] Agamben G. State of Exception, translated by Kevin Attell, The University of Chicago Press, Chicago; 2005.

[7] Emmons C. International Human Rights Law and COVID-19 States of Emergency, VerfBlog, 2020/4/25. Available from: https://verfassungsblog.de/international-human-rights-law-and-covid-19states-of-emergency/, accessed on 24.04.2020.

[8] Yildiz A. Human Rights in a State of Emergency, IACL-AIDC Blog; 26 March

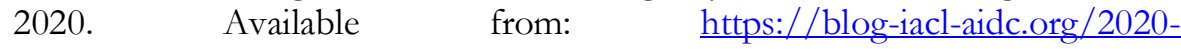
posts $/ 2020 / 3 / 26 /$ human-rights-in-a-state-of-emergency , accessed on 25.04.2020.

[9]Trace Together, Safer Together (A Singapore Government Agency website). Available from: https://www.tracetogether.gov.sg , accessed on 24.04.2020.

[10] The States Times. Available from https://www.straitstimes.com/singapore/coronavirus-spore-government-tomake-its-contact-tracing-app-freely-available-to, accessed on 25.04.2020.

[11]eHealth Network, Mobile Applications to support contact tracing in the EU's fight against Covid-19. Common EU Toolbox for Member States, Version 1, April 15th, 2020 Available from: https://ec.europa.eu/health/sites/health/files/ehealth/docs/covid19 apps en.pdf, accessed on 25.04.2020.

[12]Stopp Corona APP. Available from: https://www.roteskreuz.at/site/meet-thestopp-corona-app/\#, accessed on 25.04.2020. 
[13] Pan-European Privacy-Preserving Proximity Tracing (PEPP-PT), Content Section. Available from; https://www.pepp-pt.org/, accessed on 23.04.2020.

[14]The Polish 'selfie' app and its functionality. Available from: https://www.abc.net.au/news/2020-04-25/coronavirus-poland-trackingquarantine-selfie-app/12173884, accessed on 24.04.2020.

[15] COMM (2020) C-124 I/01 Guidance of apps supporting the fight against Covid-19 in relation to data protection, April 17th, Brussels. Available from: https://eur-lex.europa.eu/legal-

content/EN/TXT/PDF/?uri=CELEX:52020XC0417(08)\&from=RO, accessed on 25.04.2020.

[16]European Data Protection Board, Guidelines 04/2020 on the use of location data and contact tracing tools in the context of Covid-19 outbreak, adopted on April 21st, Brussle. Available from: https://edpb.europa.eu/sites/edpb/files/files/file1/edpb guidelines 202004 20 contact tracing covid_with_annex_en.pdf, accessed on 24.04.2020.

[17] Guidance from European Data Protection Board requested by Head of Unit European Commission DG for Justice and Consumers Unit C.3 - Data protection on April 14th, Brussels. Available from: https://edpb.europa.eu/sites/edpb/files/files/file1/edpbletterecadvisecodivappguidance final.pdf, accessed on 26.04.2020.

[18] Berti R., Longo A, Zanetti S. Immuni, cos'è e come funziona l'app italiana coronavirus. Available from: https://www.agendadigitale.eu/culturadigitale/immuni-come-funziona-lapp-italiana-contro-il-coronavirus/, accesed on 25.04.2020.

[19]Rustico F. Italy to use contact tracing app to track people who test positive to Covid-19, retrieved from https://www.romeing.it/coronavirus-italy-contacttracing-app/,accessed on 24.04.2020.

[20] Big Data Institute, Digital contact tracing can slow or even stop corona virus transmission and ease us out of lockdown. Available from: https://www.bdi.ox.ac.uk/news/digital-contact-tracing-can-slow-or-evenstop-coronavirus-transmission-and-ease-us-out-of-lockdown, accessed on 24.04.2020.

[21]Data reportal. Digital 2020: Global digital overview. https://datareportal.com/reports/digital-2020-global-digitaloverview?fbclid=IwAR1yexG9FQ Bu0cUy0 73mR5 hbVhfZdITAE6uDLQ KXrPpkicieg801Bej4, accessed on 28.04.2020.

[22]Huang Y, Sun M, Sui Y. How Digital Contact Tracing Slowed Covid-19 in East Asia, Harvard Business Review, retrieved from https://hbr.org/2020/04/how-digital-contact-tracing-slowed-covid-19-ineast-asia and accessed in 28.04.2020.

[23]Swiss National Covid-19 Science Task Forcer. Available from: https://ncstf.ch/en, accessed on 30.04.2020. 
[24] Kelion L. Apple and Google accelerate coronavirus contact tracing apps plan, BBC News April 24th 2020. Available from: https://www.bbc.com/news/technology-52415593, accessed on 27. 04.2020.

[25]Rory C-J. Coronavirus: UK contact-tracing app 'ready in two to three weeks', BBC News Available from: https://www.bbc.com/news/technology52458759, accessed on 30.04.2020.

[26] The Straits Times. Available from: https://www.straitstimes.com/tech/googlelaunches-new-toolto-help-public-health-officials-plan-social-distancingmeasures, accessed on 25.04.2020. 